\title{
Methodological Agreement between Body-Composition Methods in Young Soccer Players Stratified by Zinc Plasma Levels
}

\author{
Acuerdo Metodológico entre los Métodos de Composición Corporal en Jugadores \\ Jóvenes de Fútbol Estratificados por los Niveles Plasmáticos de Zinc
}

\begin{abstract}
Astrogildo Vianna de Oliveira-Junior,***; Gustavo Casimiro-Lopes**; Carmem Marino Donangelo ${ }^{* * * *}$; Josely Correa Koury $^{* * * * *}$; Paulo de Tarso Veras Farinatti"** Luís Massuça ${ }^{*, * * * * * *}$ \& Isabel Fragoso*
\end{abstract}

DE OLIVEIRA-JUNIOR, A. V.; CASIMIRO-LOPES, G.; DONANGELO, C. M.; KOURY, J. C.; FARINATTI, P. T. V.; MASSUÇA, L. \& FRAGOSO, I. Methodological agreement between body-composition methods in young soccer players stratified by zinc plasma levels. Int. J. Morphol., 34(1):49-56, 2016.

SUMMARY: It is feasible to think that the body composition assessment may be influenced by maturational and zinc status, especially in young athletes, which perform regularly high volume of physical training. In accordance, it seems important to clarify the impact of these factors in body composition assessment in athletes, since errors may lead to mistakes in training prescription and diet elaboration, and therefore affect the athletic performance. The objective was to compare (1) different methods of body composition evaluation in young soccer players stratified by zinc plasma levels; and (2) the two reference methods using skinfolds thickness in children (Slaughter's and Lohman's equations), considering the maturation level. In this cross-sectional study, fifty tree young soccer players $(13.3 \pm 0.7 \mathrm{y})$ were submitted to blood collection, electric bioimpedance (BIA), dual energy X-ray absorptiometry (DXA), anthropometric measures (body mass, stature and skinfolds thickness (ST)) and hand-wrist X-ray. Body composition evaluation was performed by: DXA, ST (Lohman and Slaughter equations) and BIA (Houtkooper equation) methods. Zinc status provided two groups: Normozincemic and Hypozincemic athletes, determined by cut-off point of $11.0 \mu \mathrm{mol} / \mathrm{L}$. Significant difference on descriptive data for all participants after zinc status stratification was observed only for plasma zinc concentration; (2) Significant correlations were observed between the assessment methods (fat percentage: $r=0.34$ to 0.98 and $p<0.001$ to 0.013 ; fat free mass: $r=0.95$ to 0.9998 and $p<0.001$ ), and lowers correlations were observed when electric impedance was involved; and (3) Bland-Altman plots across methods showed a closer agreement when DXA and ST were compared. In conclusion (1) The ST method was better than BIA to assess the body composition (in young soccer players) when DXA scans are not available; (2) The comparison of models based on ST showed that the best association with the values from DXA were obtained for the Slaughter equation, followed by the Lohman equation using bone age instead of chronological age; and (3) Plasma zinc levels seem not to influence the body composition assessment, which certainly warrants further studies.

KEY WORDS: Body composition; Youth; Nutrition; Methodology; Measurement.

\section{INTRODUCTION}

The correct assessment of body composition in sports is important, since errors may lead to mistakes in training prescription and diet elaboration, and therefore affect the athletic performance. In sports like soccer, a gravitational sport (Ackland et al., 2012), it is well known that excessive fat mass compromises the physical performance, while increased lean body mass is important to improve strength and power, which are relevant to soccer performance (Nikolaidis \& Vassilios-Karydis, 2011).
Hence sophisticated methods like dual energy X-ray absorptiometry (DXA) have been used in research sets to assess the body composition. However this kind of technique is highly expensive and somewhat difficult to be applied in actual training context. Therefore, more accessible methods like skinfolds thickness (ST) and bioelectric impedance (BIA) have been investigated as alternative options to assess the body composition.

Faculdade de Motricidade Humana, Universidade Técnica de Lisboa, Lisboa, Portugal.

** Instituto de Educação Física e Desportos, Universidade do Estado do Rio de Janeiro, Rio de Janeiro, Brasil.

*** Instituto de Bioquímica, Universidade Federal do Rio de Janeiro, Rio de Janeiro, Brasil.

***** Instituto de Nutrição, Universidade do Estado do Rio de Janeiro, Rio de Janeiro, Brasil.

****** Faculdade de Educação Física e Desporto, Universidade Lusófona de Humanidades e Tecnologias, Lisboa, Portugal. 
On the other hand, the body composition estimation in young athletes is problematic, since muscle mass, fat mass, bone mass, and hydration status can be directly influenced by the maturational process (Lohman, 1986). In this sense, nutritional and maturational aspects of athletes constitute a fundamental issue in physical performance. One of the elements simultaneously related to maturation and nutrition is the ingestion of zinc, an essential micronutrient for adequate body function.

Zinc is an essential trace element with relevant functions in many pathophysiological mechanisms. It is a cofactor in numerous transcription processes and enzymes (Lansdown et al., 2007). Zinc deficiency seems to be related with deleterious effects in formation and maturation of spermatozoa, testicular growth, and testicular steroidogenesis (Nriagu, 2007). It is well known that physical exercise can modulate the bioavailability and kinetics of this important mineral (Buchman et al., 1998; Koury et al., 2005). Additionally, zinc participates in the synthesis and liberation of factors that may influence the body composition and strength, like growth hormone, insulin-like growth factor-1, leptin and testosterone (Chen et al., 2000; Devine et al., 1998; Prasad et al., 1996).

It is therefore feasible to think that the body composition assessment may be influenced by maturational and zinc status, especially in young athletes, which perform regularly high volume of physical training. It would be useful to investigate whether different strategies to assess body composition are affected by these factors. Additionally it is important to know if the zinc status could be related to the body composition of athletes that play in the same age category. Thus the aim of this study was to compare different methods of body composition evaluation (DXA, BIA, and skinfolds thickness) in young soccer players stratified by zinc plasma levels. A secondary purpose was to compare the two reference methods using skinfolds thickness in children (Slaughter's \& Lohman's equations) (Slaughter et al., 1988), considering the maturation level.

\section{MATERIAL AND METHOD}

Sudy design: Cross-sectional study. Fifty-tree young soccer players aged 11.8 to $14.2 \mathrm{y}$ (age, $13.3 \pm 0.7 \mathrm{y}$ ), and past $6.1 \pm 2.3$ $\mathrm{y}$ of regular soccer training in a first division soccer team in Rio de Janeiro (training volume was $5.0 \pm 1.8 \mathrm{~h}$ per week), participated of the study. Zinc status was determined and athletes were classified in Normozincemic (Normo; $n=37$ ) or Hypozincemic (Hypo; $n=16$ ). During the study none of the athletes consumed any kind of dietary supplements, which could influence physiological mineral balance. Exclusion criteria were: injuries or any other medical contra-indication to physical training, irregular training pattern, chronological age lower than $11 \mathrm{y}$, and zinc deficiency. Their parents provided written consent to children's participation in the study. The study was previously approved by institutional ethics committee (Reference: 1207 CEP/HUPE UERJ).

Data collection was made in two days. In the first day the following procedures took place: (1) blood collection after 8-h fasting; (2) BIA; (3) brief meal; (4) anthropometry and hand-wrist X-ray to bone age determination; and (5) assessment of body mass and stature. Anthropometric measures were made according to procedures of the International Society for the Advancement of Kinanthropometry (ISAK) (Marfell-Jones et al., 2006). A single trained evaluator performed all procedures with satisfactory reliability $(\mathrm{ICC}=0.98-0.84)$. In the second day DXA exam was performed. Figure 1 illustrates the sequence of procedures adopted in the study.

Body composition evaluation was performed by DXA, skinfold thickness (ST), and BIA methods for comparison and further analysis of agreement. DXA exam was made using a pediatric bone densitometer (Lunar Prodigy Advance General EletricsTM, Chalfont St. Giles, United Kingdom) to whole body analysis using specific software (enCORETM Software Platform - Chalfont St. Giles, United Kingdom). The following skinfold thickness were measured as described

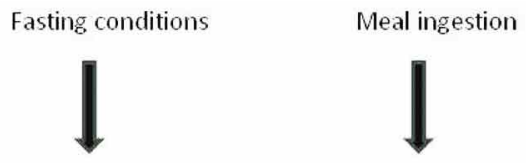

Blood colection BIA Anthropometry Hand-wristX-rays Day 1

Fig. 1. Flowchart of this cross-sectional study. 
elsewhere (Marfell-Jones et al., 2006): triceps, biceps, subscapular, chest, axillar, iliocristal, supraspinal, abdominal, thigh and calf. All measurements were performed three times with a LangeTM caliper (Santa Cruz, CA, USA) and the mean value was recorded as final result. The percent body fat was calculated using equations proposed by Slaughter et al. and Lohman that consider chemical maturity. Since the Lohman's equation includes the age, both chronological (CA) and bone age (BA) were used to allow a more comprehensive analysis. Comparisons of whole body subcutaneous fat as represented by the sum of ten skinfolds with the two skinfolds used in Slaughter's equation and the two used in Lohman's equation were satisfactory, as suggested by Pearson correlation $(r=0.923$ and $r=0.911)$ (Gutin et al., 1996). BIA assessment used a tetrapolar device (RJL-101 QuantumTM; Clinton Twp, MI, USA) and calculation of body composition was provided by the equation described by Houtkooper (Houtkooper et al., 1992). All measurements were performed in the morning with controlled temperature $\left(21\right.$ to $\left.26^{\circ} \mathrm{C}\right)$ and after bladder emptying. Electrodes were placed after metallic removal of any pieces in contact with the body, in supine position with arms and legs slightly separated by $30^{\circ}$ and $40^{\circ}$, respectively. Surface electrodes were placed at the right side of the body on the dorsal surface of hands and feet, proximal to metacarpal-phalangeal, and metatarsal-phalangeal joints, respectively, and also medially between the distal prominences of radius and ulna and between medial and lateral malleoli at the ankle (Lukaski \& Johnson, 1985). Since dehydration status could influence BIA results, we also ran blood test of some parameters related to hydration status (albumin, hematrocrit, and hemoglobin). All these data were within normal ranges expected for young athletes.

Blood collection was done after an overnight fast (8 h) together with a minimum of $16 \mathrm{~h}$ of abstention from any physical exercise. Aliquots of $10 \mathrm{~mL}$ were obtained by venous puncture in antecubital vein and placed in test tubes without trace minerals containing heparin as anticoagulant (30 U/tube). Precautions were taken to avoid trace mineral contamination during sample collection and processing. All materials were immersed for $24 \mathrm{~h}$ in a solution of ultrapure nitric acid $(4: 1 ; \mathrm{v} / \mathrm{v})$ followed by thorough rising (four times) with deionized water. Samples were centrifuged during $15 \mathrm{~min}$ at $800 \mathrm{~g}$ for plasma separation and immediately stored at $-20{ }^{\circ} \mathrm{C}$ in the laboratory for posterior analysis. Plasma zinc was measured by flame atomic absorption spectrometry (OptimaTM 4300 DV, PerkinElmer Norwalk, CT, EUA), as described elsewhere (Donangelo et al., 2002). Zinc status was determined by cut-off point of $11.0 \mu \mathrm{mol} / \mathrm{L}$ (National Research Council \& Food and Nutrition Board, 2001), which provided two groups: Normozincemic (Normo) and Hypozincemic (Hypo) athletes.

Statistical analysis. Data were normally distributed as defined by the Kolmogorov-Smirnov test, except fat percentage. Therefore intergroup comparisons were performed by oneway ANOVA test followed by Bonferroni post hoc comparisons or Kruskal-Wallis test followed by Dunns post hoc comparisons. The relationships between body composition methods were calculated by Pearson correlation and degree of agreement was tested by Bland-Altman plots. In all cases the significance level was fixed at 0.05 . The calculations were performed by the softwares GraphPad Prism 5 (GraphPadTM Software, San Diego, CA, USA) and NCSS 2007 (NCSSTM, LLC, Kaysville, UT, USA).

\section{RESULTS}

Table I presents descriptive data for all participants after zinc status stratification, showing significant differences only for plasma zinc concentration.

Fat percentage $(\% \mathrm{FM})$ and fat free mass (FFM) obtained by DXA, skinfolds thickness and BIA methods did not show any significant differences in groups stratified by zinc status or in the different methods. Results are presented in Table II.

Table I. Descriptive data of individuals, expressed as mean and standard deviation.

\begin{tabular}{|c|c|c|c|c|}
\hline & $\begin{array}{c}\text { All } \\
(\mathrm{n}=53)\end{array}$ & $\begin{array}{l}\text { Hypo } \\
(\mathrm{n}=16)\end{array}$ & $\begin{array}{l}\text { Normo } \\
(\mathrm{n}=37)\end{array}$ & $p$ \\
\hline Chronogical age (years) & $13.3 \quad \pm 0.7$ & $13.3 \pm 0.6$ & $13.3 \pm 0.7$ & 0.098 \\
\hline Bone age (years) & $13.2 \pm 2.0$ & \pm 2.5 & \pm 1.8 & 0.580 \\
\hline Bone age-Chronological age (years) & -0.12 & -0.34 & -0.02 & 0.557 \\
\hline Plasma zinc $\left(\mu \mathrm{mol} . \mathrm{L}^{-1}\right)$ & $12.2 \pm 2.2$ & \pm 1.3 & \pm 1.5 & $<0.00$ \\
\hline Total body mass (kg) & 48.4 & \pm 9.8 & \pm 10.2 & 0.249 \\
\hline Stature $(\mathrm{cm})$ & $160.1 \pm 10$. & 159.3 & \pm 10.2 & 0.730 \\
\hline Body mass index $\left(\mathrm{kg} / \mathrm{m}^{2}\right)$ & 18.7 & \pm 1.8 & \pm 2.3 & 0.084 \\
\hline
\end{tabular}

Legend: Hypo, hypozincemics; Normo, normozincemics. 
DE OLIVEIRA-JUNIOR, A. V.; CASIMIRO-LOPES, G.; DONANGELO, C. M.; KOURY, J. C.; FARINATTI, P. T. V.; MASSUÇA, L. \& FRAGOSO, I. Methodological agreement between body-composition methods in young soccer players stratified by zinc plasma levels. Int. J. Morphol., 34(1):49-56, 2016.

Table II. Comparison between the difference in fat percentage and fat free mass between different methods, considering zinc state.

\begin{tabular}{|c|c|c|c|c|c|c|c|c|c|c|}
\hline \multirow[b]{3}{*}{ DXA } & \multicolumn{5}{|c|}{ Fat percentage } & \multicolumn{5}{|c|}{ F at free mass } \\
\hline & \multicolumn{2}{|c|}{$\begin{array}{l}\text { Нypo } \\
(\mathrm{n}=16)\end{array}$} & \multicolumn{2}{|c|}{$\begin{array}{l}\text { Normo } \\
(\mathrm{n}=37)\end{array}$} & \multirow{2}{*}{$\begin{array}{c}p \\
0.635\end{array}$} & \multicolumn{2}{|c|}{$\begin{array}{l}\text { Нyро } \\
(\mathrm{n}=16)\end{array}$} & \multicolumn{2}{|c|}{$\begin{array}{l}\text { Normo } \\
(\mathrm{n}=37)\end{array}$} & \multirow{2}{*}{$\begin{array}{r}p \\
0.45\end{array}$} \\
\hline & 12.0 & \pm 4.8 & 13.7 & \pm 7.4 & & 40.4 & \pm 9.1 & 42.5 & \pm 8.7 & \\
\hline ST L (ca) & 12.2 & \pm 2.7 & 14.8 & \pm 6.6 & 0.374 & 40.3 & \pm 8.6 & 41.8 & \pm 7.4 & 0.51 : \\
\hline ST L (ba) & 12.4 & \pm 2.7 & 14.8 & \pm 6.6 & 0.402 & 40.2 & \pm 8.8 & 41.9 & \pm 7.6 & 0.50 \\
\hline ST S & 13.6 & \pm 3.2 & 15.4 & \pm 7.3 & 0.664 & 39.6 & \pm 8.3 & 41.6 & \pm 8.1 & 0.421 \\
\hline BIA & 14.6 & \pm 5.1 & 14.6 & \pm 6.8 & 0.848 & 39.3 & \pm 8.9 & 42.4 & \pm 9.8 & 0.29 \\
\hline$p$ & & & & & & 0.9 & & & & \\
\hline
\end{tabular}

DXA, dual energy X-ray absortiometry; ST, skinfold tickness; L, Lohman equation; S, Slaughter equation; ca, chronological age; ba, bone age; BIA, eletric bioimpedance; hypo, hypozincemics; normo, normozincemics.

Correlations between the assessment methods showed significant associations between the methods. Results are presented in Table III.
Figure 2 shows the Bland-Altman plots for the comparison between groups stratified by zinc status, with regard to the fat percentage provided by the four assessment

Table III. Spearman correlation coefficients between body fat percent provided by the different methods $(n=53)$.

\begin{tabular}{lcccccc}
\hline & & DXA & ST L (ca) & ST L (ba) & ST S & BIA \\
\hline DXA & $r$ & -- & 0.780 & 0.831 & 0.875 & 0.630 \\
& $p$ & -- & $<0.001$ & $<0.001$ & $<0.001$ & $<0.001$ \\
\multirow{2}{*}{ ST L (ca) } & $r$ & 0.780 & -- & 0.977 & 0.898 & 0.780 \\
& $p$ & $<0.001$ & -- & $<0.001$ & $<0.001$ & $<0.001$ \\
\multirow{2}{*}{ ST L (ba) } & $r$ & 0.831 & 0.977 & -- & 0.895 & 0.428 \\
& $p$ & $<0.001$ & $<0.001$ & -- & $<0.001$ & 0,002 \\
ST S & $r$ & 0.875 & 0.898 & 0.895 & -- & 0.438 \\
& $p$ & $<0.001$ & $<0.001$ & $<0.001$ & -- & $<0.001$ \\
\multirow{2}{*}{ BIA } & $r$ & 0.630 & 0.341 & 0.428 & 0.437 & -- \\
& $p$ & $<0.001$ & 0.013 & 0.002 & 0.001 & -- \\
\hline
\end{tabular}

DXA= dual energy X-ray absortiometry; ST= skinfold tickness; L= Lohman equation; $\mathrm{S}=$ Slaughter equation; $\mathrm{ca}=$ chronological age; $\mathrm{ba}=$ bone age; $\mathrm{BIA}=$ electric bioimpedance; $\mathrm{hypo}=$ hypozincemics; normo $=$ normozincemics.

Table IV. Pearson correlation coefficients between fat free mass provided by the different methods $(n=53)$.

\begin{tabular}{lcccccc}
\hline & & DXA & ST L (ca) & ST L (ba) & ST S & BIA \\
\hline DXA & $r$ & -- & 0.989 & 0.989 & 0.9899 & 0.966 \\
& $p$ & -- & $<0.001$ & $<0.001$ & $<0.001$ & $<0.001$ \\
\multirow{2}{*}{ ST L (ca) } & $r$ & 0.989 & -- & 0.9998 & 0.985 & 0.963 \\
& $p$ & $<0.001$ & -- & $<0.001$ & $<0.001$ & $<0.001$ \\
\multirow{2}{*}{ ST L (ba) } & $r$ & 0.989 & 0.9998 & -- & 0.986 & 0.963 \\
& $p$ & $<0.001$ & $<0.001$ & -- & $<0.001$ & $<0.001$ \\
ST S & $r$ & 0.990 & 0.985 & 0.986 & -- & 0.953 \\
& $p$ & $<0.001$ & $<0.001$ & $<0.001$ & -- & $<0.001$ \\
\multirow{2}{*}{ BIA } & $r$ & 0.966 & 0.963 & 0.963 & 0.953 & -- \\
& $p$ & $<0.001$ & $<0.001$ & $<0.001$ & $<0.001$ & -- \\
\hline
\end{tabular}

DXA= dual energy X-ray absortiometry; $\mathrm{ST}=$ skinfold tickness; $\mathrm{L}=$ Lohman equation; $\mathrm{S}=$ Slaughter equation; $\mathrm{ca}=$ chronological age; $\mathrm{ba}=$ bone age; $\mathrm{BIA}=$ electric bioimpedance; $\mathrm{hypo}=$ hypozincemics; normo $=$ normozincemics. 
DE OLIVEIRA-JUNIOR, A. V.; CASIMIRO-LOPES, G.; DONANGELO, C. M.; KOURY, J. C.; FARINATTI, P. T. V.; MASSUÇA, L. \& FRAGOSO, I. Methodological agreement between body-composition methods in young soccer players stratified by zinc plasma levels. Int. J. Morphol., 34(1):49-56, 2016.
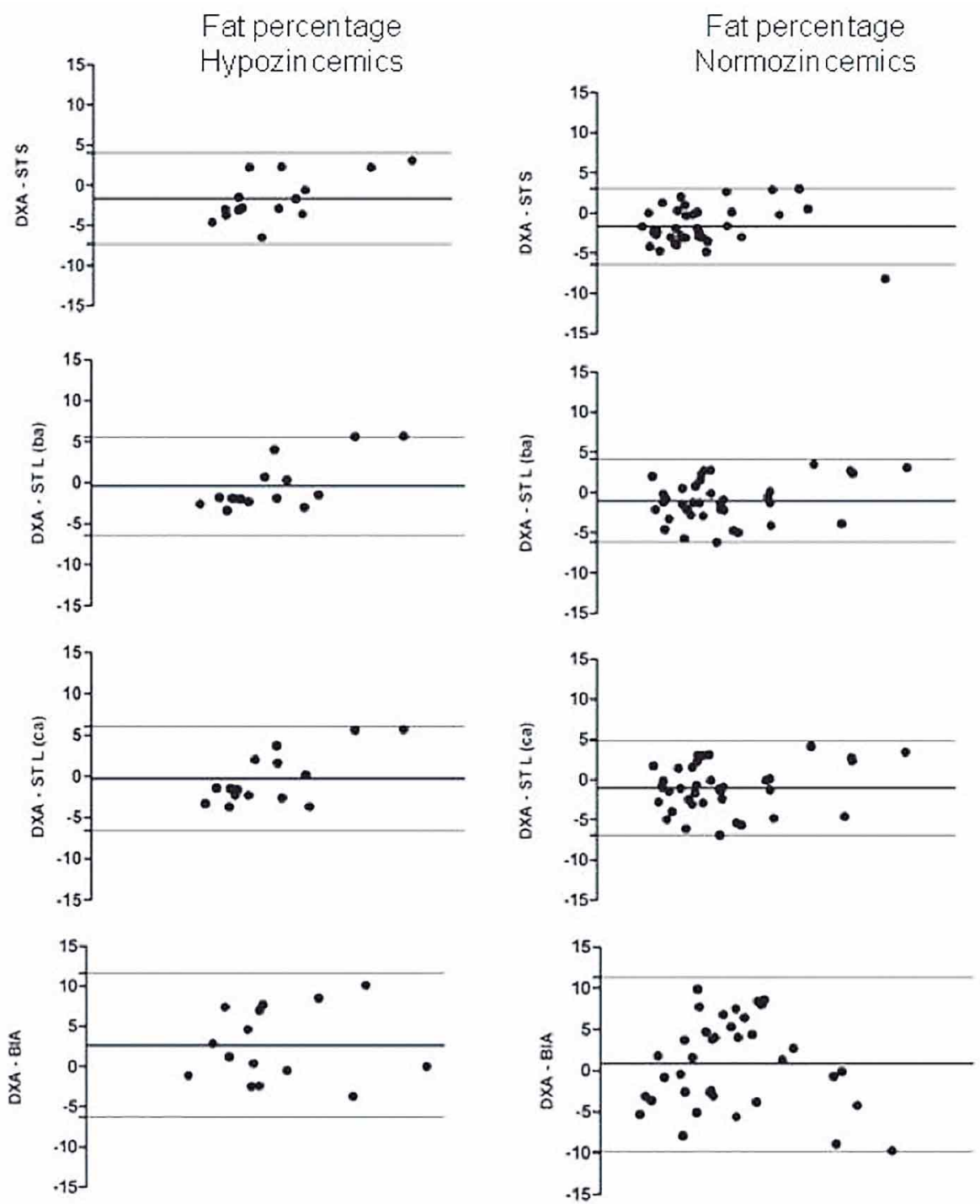

Fig. 2. Bland-Altman analysis comparing differences between fat percent assessed by bioimpedance (BIA), dual energy X-ray absorptiometry (DXA), and skinfolds thickness (ST) (L, Lohman equation; S, Slaughter equation; ca, chronological age; ba, bone age).

methods. There was a close agreement when DXA and ST were compared depending of zinc status (bias $=-1.61$ [hypozincemics] and -1.62 [normozincemics] - Slaughter equation; -0.24 and -1.05 - Lohman equation / chronological age; -0.40 and -1.02 - Lohman equation / bone age, respectively), however such agreement was not detected when the comparison was done with DXA-BIA (2.64 and $0.83)$. Results are presented graphically in Figure 2.

Bland-Altman plots across methods and zinc groups were also calculated for the fat free mass. A close agreement was detected when DXA and ST were compared depending of zinc status (bias $=0.89$ [hypozincemics] and 0.85 [normozincemics] - Slaughter equation; -0.63 and -0.23 -
Lohman equation / bone age; -0.69 and 0.19 - Lohman equation / chronological age, respectively), which was not observed in the DXA and BIA methods. Results are presented graphically in Figure 3.

\section{DISCUSSION}

The present study aimed to evaluate the influence of zinc status on the body composition assessment by three different methods (DXA, BIA and ST). Interestingly, Pearson`s correlation coefficients showed strong intragroup associations in fat free mass between hypozincemic and 
DE OLIVEIRA-JUNIOR, A. V.; CASIMIRO-LOPES, G.; DONANGELO, C. M.; KOURY, J. C.; FARINATTI, P. T. V.; MASSUÇA, L. \& FRAGOSO, I. Methodological agreement between body-composition methods in young soccer players stratified by zinc plasma levels. Int. J. Morphol., 34(1):49-56, 2016.
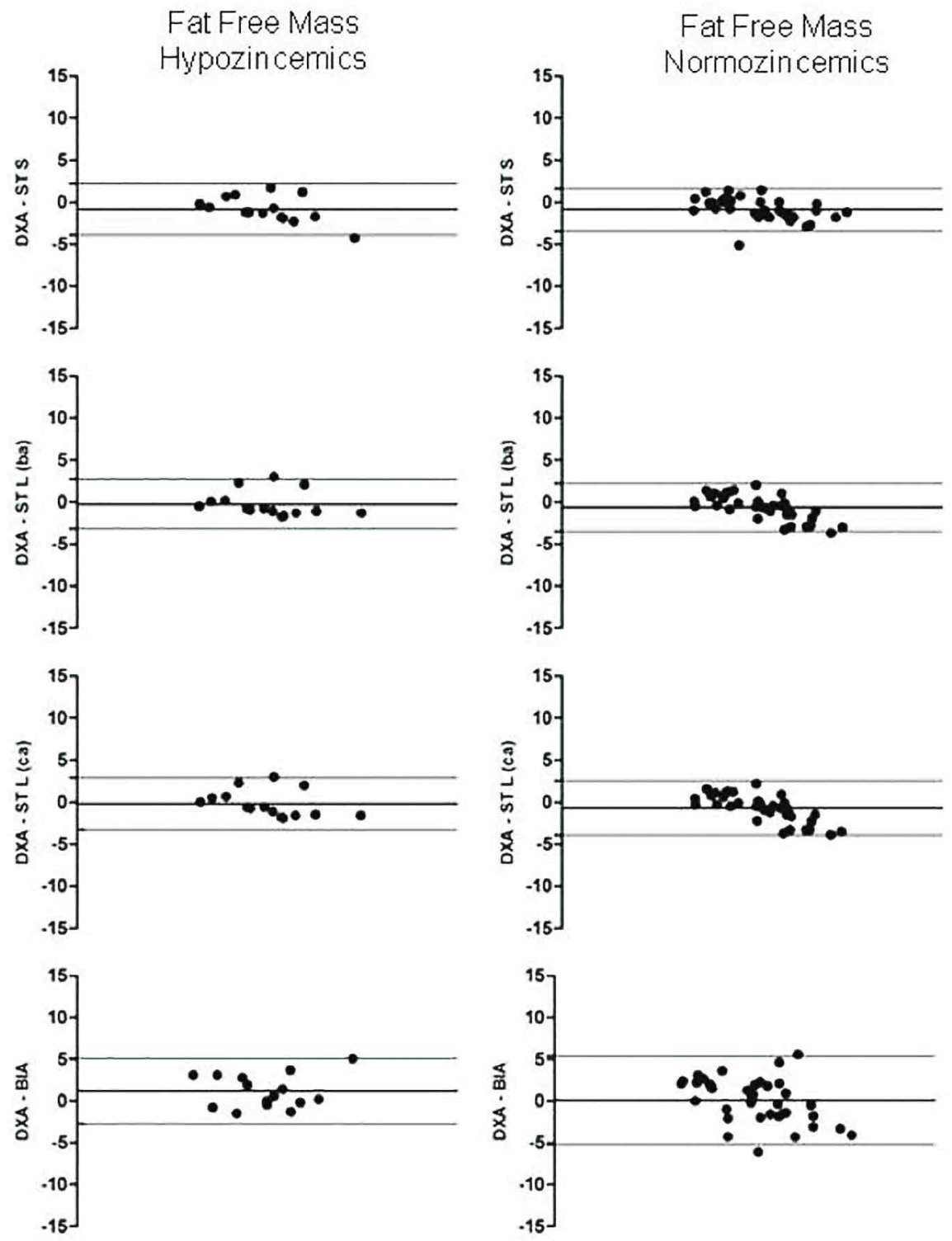

Fig. 3. Bland-Altman analysis comparing differences between fat free mass assessed by bioimpedance (BIA), dual energy X-ray absorptiometry (DXA), and skinfolds thickness (ST) (L, Lohman equation; S, Slaughter equation; ca, chronological age; ba, bone age).

normozincemic athletes, suggesting that plasma zinc levels could not influence the association between body composition parameters evaluated by the different methods. In a previous study, our group reported a negative correlation of zinc/copper ratio with percent body fat assessed by DXA, suggesting that lower zinc levels would be related to increased fat mass (Koury et al., 2007). Indeed zinc may influence the adipose tissue physiology, probably due to the recently described zinc $\partial 2$-glycoprotein, a lipid mobilizing factor (Bao et al., 2005). Additionally, zinc levels are positively associated with leptin concentrations
(Chen et al.; Casimiro-Lopes et al., 2009) and with thyroid hormones (Marques et al., 2011), which play an important role in fat metabolism.

Another purpose of our study was to compare assessment techniques in order to confirm that alternative and more accessible methods to assess the body composition could be used in field studies. The three equations based on skinfolds thickness (Slaughter and Lohman using CA and BA) provided similar results. When we observe \%FM there is an increase in the correlation 
strength of Lohman equation by CA with DXA, through the Lohman equation by BA to the Slaughter equation. Nevertheless, for FFM differences are smaller.

Bland-Altman plots are adequate to investigate the agreement between measurements, when the main focus is to compare a new method (or methodology) with a goldstandard approach (Altman \& Bland, 1983; Bland \& Altman, 1986). In fact, were observed that ST technique was the best method when compared with DXA, at least to assess the body composition in young soccer players. Interestingly, we have observed that the level of agreement also relied on zinc status. The ST method is generally accepted as a body fat indicator, since $50-70 \%$ of body fat is located in subcutaneous adipose tissue. Some authors argue against this method considering its precision and validity (Gutin et al.; Goran et al., 1996), but the relatively low cost is a positive aspect that must be considered in actual training practice.

On the other hand, our results showed that BIA did not reach satisfactory levels of agreement with DXA in young soccer players. An important issue to take into account is that BIA analysis is not adjusted for the maturation level (Houtkooper et al.), while the equations by Lohman and Slaughter $e t$ al. consider the influence of this factor. Another potential source of error is the fact that BIA is based in the electrical conductivity of different body components (muscle mass and fat mass), and may be highly affected by hydration status (Barbosa-Silva \& Barros, 2005). Since our athletes presented normal levels of hydration as confirmed by blood analysis, we can assume that the poorer agreement in comparison with the skinfolds technique was not produced by this factor.

It can be concluded that: (1) The ST method was better than BIA to assess the body composition in young soccer players when DXA scans are not available; (2) The comparison of models based on skinfolds thickness showed that the best association with the values from DXA were obtained for the Slaughter equation, followed by the Lohman equation using BA instead of CA; and (3) Plasma zinc levels seem not to influence the body composition assessment, which certainly warrants further studies.

\section{ACKNOWLEGEMENTS}

All authors have responsability for all parts of the manuscript. The authors declare that they have no conflicts of interest in the research.

DE OLIVEIRA-JUNIOR,A. V.; CASIMIRO-LOPES, G.; DONANGELO, C. M.; KOURY, J. C.; FARINATTI, P. T. V.; MASSUÇA, L. \& FRAGOSO, I. Acuerdo metodológico entre los métodos de composición corporal en jugadores jóvenes de fútbol estratificados por los niveles plasmáticos de zinc. Int. J. Morphol., 34(1):49-56, 2016.

RESUMEN: Es factible pensar que la evaluación de la composición corporal puede estar influenciada por el estado de maduración y los niveles plasmáticos de zinc, especialmente en atletas jóvenes, que regularmente realizan un alto volumen de entrenamiento físico. Por tanto, es importante aclarar el impacto de estos factores en la evaluación de la composición corporal de los atletas, ya que errores en su análisis pueden conducir al desarrollo de una equivocada prescripción de entrenamiento, además de una dieta determinada, y por lo tanto afectar el rendimiento deportivo. El objetivo de esta investigación consistió en: (1) comparar los diferentes métodos de evaluación de la composición corporal en futbolistas jóvenes estratificados por los niveles plasmáticos de zinc; (2) comparar los dos métodos de referencia utilizando el espesor de los pliegues cutáneos en niños (ecuaciones de Slaughter y Lohman), teniendo en cuenta el nivel de maduración. En este estudio transversal, cincuenta futbolistas jóvenes (13,3 $\pm 0,7$ años) fueron sometidos a un perfil bioquímico de sangre, bioimpedancia eléctrica (BIA), absorciometría de rayos X de energía dual (DXA), medidas antropométricas (masa corporal, estatura y pliegues cutáneos de espesor (ST)) y radiografía de mano-muñeca. La evaluación de la composición corporal se realizó por: DXA, ST (ecuaciones Lohman y Slaughter) y BIA (ecuación Houtkooper). El nivel de zinc identificó dos grupos: deportistas normozincémicos e hipozincémicos, determinados por un punto de corte de 11,0 mmol/L. Se observó una diferencia significativa en los datos descriptivos de todos los participantes después de la estratificación del estado de zinc sólo para la concentración de zinc en plasma; se observaron correlaciones significativas entre los métodos de evaluación (porcentaje de grasa: $\mathrm{r}=0,34$ a 0,98 y p <0,001 a 0,013; masa libre de grasa: $\mathrm{r}=$ desde 0,95 hasta 0,9998 y p <0,001), y disminuyeron las correlaciones al estar involucrada la impedancia eléctrica. Los resultados a través de los métodos Bland y Altman mostraron un acuerdo más cercano al comparar DXA y ST. El método ST fue mejor que el BIA para evaluar la composición corporal (en los jugadores jóvenes de fútbol), cuando no estaban disponibles los escaneos DXA. La comparación de los modelos basados en ST mostró que la mejor asociación de valores DXA se obtuvieron para la ecuación Slaughter, seguidos por la ecuación Lohman utilizando la edad ósea en lugar de la edad cronológica. Los niveles de zinc en plasma parecen no influir en la evaluación de la composición corporal, lo que amerita más estudios.

PALABRAS CLAVE: Composición corporal; Jóvenes; Nutrición ; Metodología; Medidas. 


\section{REFERENCES}

Ackland, T. R.; Lohman, T. G.; Sundgot-Borgen, J.; Maughan, R. J.; Meyer, N. L.; Stewart, A. D. \& Müller, W. Current status of body composition assessment in sport: review and position statement on behalf of the ad hoc research working group on body composition health and performance, under the auspices of the I.O.C. Medical Commission. Sports Med., 42(3):227-49, 2012.

Altman, D. G. \& Bland, J. M. Measurement in medicine: The analysis of method comparison studies. The Statistician, 32(3): 307-17, 1983.

Bao, Y.; Bing, C.; Hunter, L.; Jenkins, J. R.; Wabitsch, M. \& Trayhurn, P. Zinc-alpha2-glycoprotein, a lipid mobilizing factor, is expressed and secreted by human (SGBS) adipocytes. F. E. B. S. Lett., 579(1):41-7, 2005.

Barbosa-Silva, M. C. \& Barros, A. J. Bioelectrical impedance analysis in clinical practice: a new perspective on its use beyond body composition equations. Curr. Opin. Clin. Nutr. Metab. Care, 8(3):311-7, 2005.

Bland, J. M. \& Altman, D. G. Statistical methods for assessing agreement between two methods of clinical measurement. Lancet, 1(8476):307$10,1986$.

Buchman, A. L.; Keen, C.; Commisso, J.; Killip, D.; Ou, C. N.; Rognerud, C. L.; Dennis, K. \& Dunn, J. K. The effect of a marathon run on plasma and urine mineral and metal concentrations. J. Am. Coll. Nutr., 17(2):124-7, 1998

Casimiro-Lopes, G.; de Oliveira-Junior, A. V.; Portella, E. S.; Lisboa, P. C.; Donangelo, C. M.; de Moura, E. G. \& Koury, J. C. Plasma leptin, plasma zinc, and plasma copper are associated in elite female and male judo athletes. Biol. Trace Elem. Res., 127(2):109-15, 2009.

Chen, M. D.; Song, Y. M. \& Lin, P. Y. Zinc may be a mediator of leptin production in humans. Life Sci., 66(22):2143-9, 2000.

Devine, A.; Rosen, C.; Mohan, S.; Baylink, D. \& Prince, R. L. Effects of zinc and other nutritional factors on insulin-like growth factor I and insulin-like growth factor binding proteins in postmenopausal women. Am. J. Clin. Nutr., 68(1):200-6, 1998.

Donangelo, C. M.; Woodhouse, L. R.; King, S. M.; Viteri, F. E. \& King, J. C. Supplemental zinc lowers measures of iron status in young women with low iron reserves. J. Nutr., 132(7):1860-4, 2002.

Goran, M. I.; Driscoll, P.; Johnson, R.; Nagy, T. R. \& Hunter, G. Crosscalibration of body-composition techniques against dual-energy Xray absorptiometry in young children. Am. J. Clin. Nutr., 63(3):299305, 1996.

Gutin, B.; Litaker, M.; Islam, S.; Manos, T.; Smith, C. \& Treiber, F. Bodycomposition measurement in 9-11-y-old children by dual-energy Xray absorptiometry, skinfold-thickness measurements, and bioimpedance analysis. Am. J. Clin. Nutr., 63(3):287-92, 1996.

Houtkooper, L. B.; Going, S. B.; Lohman, T. G.; Roche, A. F. \& Van Loan, M. Bioelectrical impedance estimation of fat-free body mass in children and youth: a cross-validation study. J. Appl. Physiol. (1985), 72(1):36673, 1992.

Koury, J. C.; de Oliveira, C. F.; Portella, E. S.; Oliveira, A. V. Jr. \& Donangelo, C. M. Effect of the period of resting in elite judo athletes: hematological indices and copper/ zinc-dependent antioxidant capacity. Biol. Trace Elem. Res., 107(3):201-11, 2005.

Koury, J. C.; de Oliveira, K. J.; Lopes, G. C.; de Oliveira, A. V. Jr.; Portella, E. S.; de Moura, E. G. \& Donangelo, C. M. Plasma zinc, copper, leptin, and body composition are associated in elite female judo athletes. Biol. Trace Elem. Res., 115(1):23-30, 2007.

Lansdown, A. B.; Mirastschijski, U.; Stubbs, N.; Scanlon, E. \& Agren, M. S. Zinc in wound healing: theoretical, experimental, and clinical aspects. Wound Repair Regen., 15(1):2-16, 2007.

Lohman, T. G. Applicability of body composition techniques and constants for children and youths. Exerc. Sport Sci. Rev., 14:325-57, 1986.

Lukaski, H. C. \& Johnson, P. E. A simple, inexpensive method of determining total body water using a tracer dose of $\mathrm{D} 2 \mathrm{O}$ and infrared absorption of biological fluids. Am. J. Clin. Nutr., 41(2):363-70, 1985.

Marfell-Jones, M.; Olds, T.; Stewart, A. \& Carter, J. E. L. International Standards for Anthropometric Assessment (revised 2006). Underdale, International Society for the Advanced of Kinanthropometry, 2006.

Marques, L. F.; Donangelo, C. M.; Franco, J. G.; Pires, L.; Luna, A. S.; Casimiro-Lopes, G.; Lisboa, P. C. \& Koury, J. C. Plasma zinc, copper, and serum thyroid hormones and insulin levels after zinc supplementation followed by placebo in competitive athletes. Biol. Trace Elem. Res., 142(3):415-23, 2011.

National Research Council \& Food and Nutrition Board. Dietary Reference Intakes for Vitamin A, Vitamin K, Arsenic, Boron, Chromium, Copper, Iodine, Iron, Manganese, Molybdenum, Nickel, Silicon, Vanadium, and Zinc. Washington D. C., National Academies Press, Institute of Medicine, 2001

Nikolaidis, P. T. \& Vassilios Karydis, N. Physique and body composition in soccer players across adolescence. Asian J. Sports Med., 2(2):7582, 2011.

Nriagu, J. Zinc Deficiency in Human Health. In: Nriagu, J. (Ed.). Encyclopedia of Environmental Health. London, Elsevier Science, 2007.

Prasad, A. S.; Mantzoros, C. S.; Beck, F. W.; Hess, J. W. \& Brewer, G. J. Zinc status and serum testosterone levels of healthy adults. Nutrition, 12(5):344-8, 1996.

Slaughter, M. H.; Lohman, T. G.; Boileau, R. A.; Horswill, C. A.; Stillman, R. J.; Van Loan, M. D. \& Bemben, D. A. Skinfold equations for estimation of body fatness in children and youth. Hum. Biol., 60(5):70923, 1988.

Correspondence to:

Luís Miguel Massuça

Lusófona University

Faculty of Physical Education and Sport

Campo Grande, 376, room H.1.2.,

1749-024 Lisbon

PORTUGAL

Email: luis.massuca@gmail.com

Received: 06-05-2015

Accepted: $28-12-2015$ 